CREOLE ECONOMICS 
THIS PAGE INTENTIONALLY LEFT BLANK 


\section{Creole Economics}

C A R I B B E A N

C U N N I N G

UNDER THE

FRENCH F L A G

KATHERINE E. BROWNE

Line Drawings by Rod Salter

University of Texas Press $\mathbf{v}$ Austin 
A portion of this work previously appeared as "Creole Economics and the Débrouillard: From Slave-Based Adaptations to the Informal ..." in Ethnohistory, Vol. 49, No. 2, pp. 373-403. Copyright 2002, American Society of Ethnohistory. All rights reserved. Used by permission of the publisher.

Use of graphics from the article "The Informal Economy of Martinique," in Human Organization, Vol. 55 (2):225-234, courtesy of the Society for Applied Anthropology.

Copyright (C) 2004 by the University of Texas Press All rights reserved Printed in the United States of America First edition, 2004

Requests for permission to reproduce material from this work should be sent to Permissions, University of Texas Press, P.O. Box 7819, Austin, TX 78713-7819.

(2) The paper used in this book meets the minimum requirements of ANSI/NISO Z39.48-I992 (RI997) (Permanence of Paper).

LIBRARY OF CONGRESS

CATALOGING-IN-PUBLICATION DATA

Browne, Katherine E.

Creole economics: Caribbean cunning under the French flag / by Katherine E. Browne.

p. $\quad \mathrm{cm}$.

Includes bibliographical references and index. ISBN 0-292-70292-2 ((cl.) : alk. paper) ISBN 0-292-7058I-6 ((pbk.) : alk. paper) I. Informal sector (Economics)-Martinique. 2. Martinique-Economic conditions-1918- 3. WomenMartinique-Economic conditions. I. Title.

HD2346.M37B76 2005

$330-\mathrm{dc} 22$ 2004000551 
To Jane DeHart Albritton, my partner in all things

And to the courageous and beautiful people of Martinique who helped me understand. 
THIS PAGE INTENTIONALLY LEFT BLANK 